\title{
SISTEM PENGAMBILAN KEPUTUSAN KELAYAKAN PEMINJAMAN KREDIT DENGAN METODE AHP PADA KOPERASI KREDIT KARYA BHAKTI KOTABUMI
}

\author{
${ }^{1)}$ Merri Parida, ${ }^{2)}$ Romadon \\ ${ }^{3)}$ Septa Aditiya \\ Dosen Sistem Informasi, STMIK Dian Cipta Cendikia Kotabumi \\ E-Mail : merriparida27@gmail.com,
}

\begin{abstract}
ABSTRAK
Koperasi Kredit Karya Bhakti Kotabumi adalah salah satu Koperasi yang ada di kotabumi. Selama ini Koperasi Kredit Karya Bhakti Kotabumi khususnya dalam menentukan kelayakan peminjaman belum memanfaatkan terknologi komputerisasi dalam mengambil keputusan karna masih menggunakan proses yang manual.

Metode yang digunakan dalam penelitian tugas akhir ini adalah metode Waterfall, alat perancangan sistem yang digunakan adalah mapping chat, data flow diagram, struktur basis database, desain input, desain output, pengkodean, flowchat program, dan struktur menu aplikasi.

Hasil dari penelitian ini adalah sebuah program SPK dalam bentuk Microsof Visual Basic 6.0 yang dapat membantu team surpey dalam pengolahan data pemohoan yang akan mengajukan peminjaman kredit. Basis data yang di buat adalah DB-PEMINJAM . Dengan demikian disarankan kepada bagian Team Surpey Koperasi Kredit Karya Bhakti Kotabumi supaya menggunakan program aplikasi ini agar dalam pengambilan keputusan kelayakan peminjaman kredit dapat lebih efektif dan efisien
\end{abstract}

Kata Kunci : Waterfall, Kriteria, Peminjaman

\section{ABSTRACT}

Credit Cooperative Karya Bhakti Kotabumi is one of the cooperatives in kotabumi. During this Credit Cooperative Karya Bhakti Kotabumi especially in determining the feasibility of borrowing has not utilized computerized technology in taking decisions because it still uses a manual process.

The method used in this final project is Waterfall method, system design tool used is mapping chat, data flow diagram, database base structure, input design, output design, coding, flowchat program, and application menu structure.

The result of this research is a program of SPK in the form of Microsof Visual Basic 6.0 that can help surpey team in processing data of pemohoan who will apply for loan credit. The database that is created is DB-POLINJAM. Thus it is suggested to the Team Surpey Credit Cooperative Karya Bhakti Kotabumi to use this application program so that in making the decision of credit loan feasibility can be more effective and efficient

Keywords : Waterfall, Criteria, Lending 


\section{PENDAHULUAN}

Koperasi merupakan bentuk perusahaan organisasi dimana tujuan utamanya bukan mencari keuntungan tetapi mencari kesejahteraan dari anggotanya. Koperasi sebagai perkumpulan untuk kesejahteraan bersama, melakukan usaha dan kegiatan di bidang pemenuhan kebutuhan bersama dari para anggotannya. Koperasi mempunyai peranan yang cukup besar dalam menyusun usaha bersama dari orang-orang yang mempunyai kemampuan ekonomi terbatas.

Persaingan usaha yang sedemikian ketat memerlukan berbagai cara untuk menghadapinya, demikian juga koperasi yang merupakan badan usaha yang mencari laba tidak luput dari persaingan dengan badan usaha lainnya. Oleh karena itu koperasi perlu membenahi di berbagai bidang antara lain : bidang keuangan, bidang pemasaran, bidang personalia, bidang manajemen dan bidang operasi. Koperasi Kredit Karya Bhakti Kotabumi Lampung Utara adalah salah satu badan usaha yang mengalami kesulitan dalam penentuan kelayakan peminjaman kredit karena Untuk mendapatkan pinjaman uang anggota harus mengikuti prosedur yang berlaku di Koperasi yaitu anggota datang menemui pihak Koperasi untuk dilakukan interview, pengisian proposal dan kelengkapan data serta akan survei lapangan. Selanjutnya pihak koperasi melakukan kegiatan administrasi pinjaman. Selama ini untuk dapat menentukan siapa saja yang berhak mendapatkan pinjaman uang dengan kegiatan administrasi yang meliputi kegiatan analisis secara kuantitatif dan kualitatif memerlukan waktu yang agak lama karena data yang disajikan tidak tersimpan secara komputerisasi.

Dengan berbagai permasalahan maka perlu dibuat sistem pengambilan keputusan kelayakan peminjaman yang lebih up to date. Hal ini seiring dengan perkembangan ilmu pengetahuan dan teknologi saat ini, dimana kita tidak lagi dibatasi waktu dan tempat. manusia semakin dimudahkan dalam memperoleh suatu informasi. Kebutuhan manusia akan informasi pada saat ini menjadi begitu mudah terpenuhi dengan hadirnya Sofware, waktu dan ruang tidak lagi menjadi persoalan. Untuk kelayakan peminjaman pada Koperasi Kredit Karya Bhakti Kotabumi Lampung Utara yaitu dengan menggunakan Sofware Aplikasi. Dimana nantinya sistem ini diharapkan dapat meningkatkan mutu pelayanan kepada masyarakat umum khususnya bagi calon anggota baru.

\section{METODE PENELITIAN}

Metode yang digunakan dalam penelitian ini adalah Metode Waterfall dimana metode ini bertujuan untuk menemukan dan mengembangkan sistem baru atau yang sudah ada dalam rangka penyempurnaan dan pengembangan sehingga diperoleh hasil yang lebih efektif. Metode ini meliputi tahapan-tahapan berikut ini :

\section{A. Perencanaan Sistem}

Pada tahap ini penulis merencanakan kapan sistem akan dibangun, untuk apa, siapa pengguna dengan mengedentifikasi permasalahan yang ada melalui tahap yaitu:

1) Wawancara yaitu menanyakan langsung tentang sistem pengambilan keputusan kelayakan peminjaman kredit yang sedang berjalan.

2) Observasi dengan mengamati langsung keadaan sekitar.

3) Dokumentasi pada tahap ini penulis mengecek dokumen pemohon yang telah mendapat pinjaman.

B. Analisis (Analysis)

Pada Tahap ini penulis melakukan analisis dari dokumen, yang meliputi Arsip data pemohon yang layak untuk di pinjami 
kredit, data tempat penelitian dan data petugas.

\section{Desain Sistem}

Pada desain secara umum yang dilakukan adalah mendesain tampilan (interface), sehingga pemakai mudah dalam penggunaan. Adapun desain yang dirancang meliputi tampilan input: Tampilan form menu utama, tampilan data pemohon, data petugas, data penilaian, Tampilan Ouput meliputi : Tampilan cetak laporan.

\section{Pengkodean}

Menerjemahkan hasil proses perancangan menjadi sebuah bentuk program komputer yang dimengerti oleh mesin komputer.

\section{E. Uji coba program}

Pada tahap pengujian ini penulis melakukan pengujian kelayakan program dalam pengambilan keputusan kelayakan peminjaman kredit, yang meliputi: Pengujian Input data pemohon, pengujian hasil proses ( tambah, simpan, hapus, perbaiki, batal, keluar), pengujian database, pengujian hasil hitung penentuan kelayakan peminjaman kredit, lalu mengecek sistem untuk menemukan kesalahan - kesalahan dan menghasilkan output yang sebenarnya sesuai dengan permintaan.

\section{F. Penerapan (Implementation)}

Tahap Penerapan adalah menyeleksi semua kebutuhan yang diperlukan oleh sistem yang akan dibangun, seperti perangkat keras ( Hardware), Perangkat lunak (Sofware ).

\section{G. Pemeliharaan (Maintenance)}

Melakukan pemeliharaan perangkat lunak (Software) yang telah disampaikan kepada pemakai (user), jika mengalami perubahan - perubahan atau penambahan sesuai dengan kesalahan yang ditemukan dan permintaan dari pemakai (user)

\subsection{Landasan Teori}

\subsubsection{Sistem Pengambilan Keputusan}

Sistem Pegambilan Keputusan (Decision Support System) Sistem pendukung keputusan ialah proses pengambilan keputusan dibantu menggunakan komputer untuk membantu pengambil keputusan dengan menggunakan beberapa data dan model tertentu untuk menyelesaikan beberapa masalah yang tidak terstruktur. Sistem Pendukung Keputusan dirancang untuk mendukung seluruh tahap pengambilan keputusan mulai dari mengidentifikasikan masalah, memilih data yang relevan,dan menentukan pendekatan yang digunakan dalam proses pengambilan keputusan sampai mengevaluasi pemilihan alternatifalternatif yang ada (Fitriani, 2012).

\subsubsection{Kopersi}

Definisi Koperasi menurut Amin Widjaja dalam bukunya Akuntansi Untuk Koperasi adalah badan usaha yang beranggotakan orang atau badan hukum koperasi dengan berlandaskan kegiatan berdasarkan prinsip koperasi sekaligus sebagai gerakan ekonomi rakyat yang berdasarkan asas kekeluargaan.

\subsubsection{Kredit}

Menurut Teguh Pudjo Mulyono ( 2002:12 )“ Kredit adalah suatu penyerahan uang atau tagihan yang dapat dipersamakan dengan itu, berdasarkan persetujuan atau kesepakatan pinjam meminjam antara Bank dengan pihak lain yang mewajibkan pihak peminjam untuk melunasi hutangnya setelah jangka waktu tertentu dengan bunga jumlah imbalan atau pembagian hasil keuntungan ".

\subsubsection{Metode Pengembangan Sistem Waterfall}

Metode pengembangan sistem metode SDLC(Sistem Development Life Cycle) atau sering disebut sebagai pendekatan air terjun (waterfall).Metode waterfall pertama kali diperkenalkan oleh Windows W. Royce pada tahun 1970. Waterfall merupakan model klasik yang sederhana dengan aliran sistem yang linier Output dari setiap tahap merupakan input bagi tahap berikutnya (Kristanto, 2004).

\section{HASIL DAN PEMBAHASAN}




\subsection{Hasil Program}

\section{Tampilan Form Login}

Berikut gambar tampilan menu login.

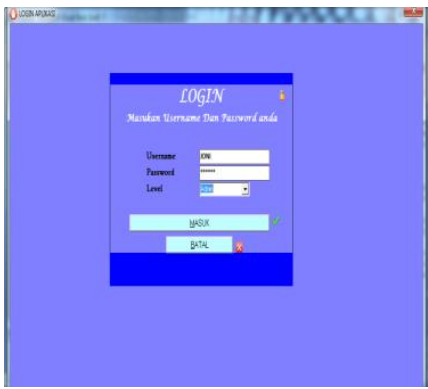

Gambar 1 Form Login

\section{Tampilan Menu Utama}

Berikut gambar tampilan menu utama

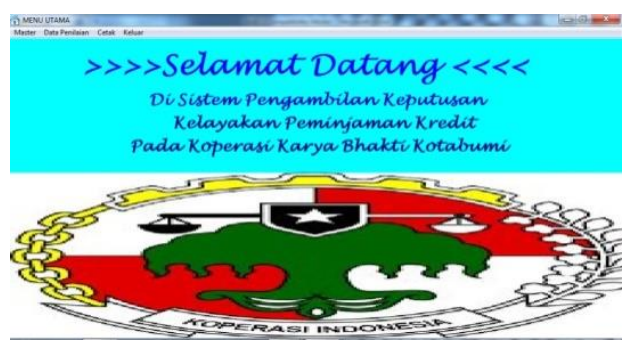

Gambar 2 Menu Utama

\section{Tampilan Menu Data Pemohon}

Berikut gambar tampilan menu data pemohon

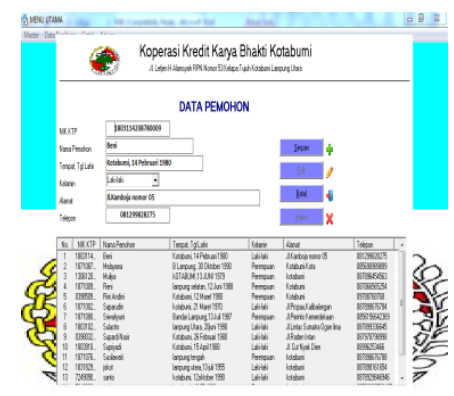

Gambar 3 Menu Data Pemohon

\section{Tampilan Menu Data Petugas}

Berikut gambar tampilan menu data petugas

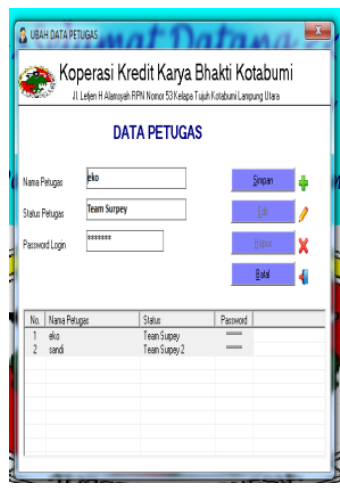

Gambar 4 Menu Data Petugas

\section{Tampilan Menu Input Nilai}

Berikut gambar tampilan menu input nilai

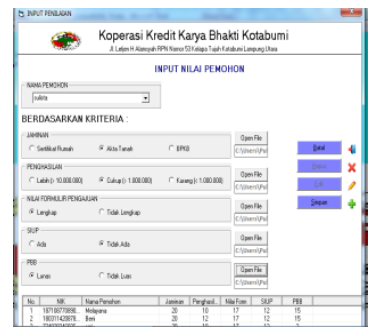

\section{Gambar 5 Menu Penilaian Pinjaman}

\section{Penilaian Pinjaman}

Berikut gambar tampilan form Penilaian Pinjaman

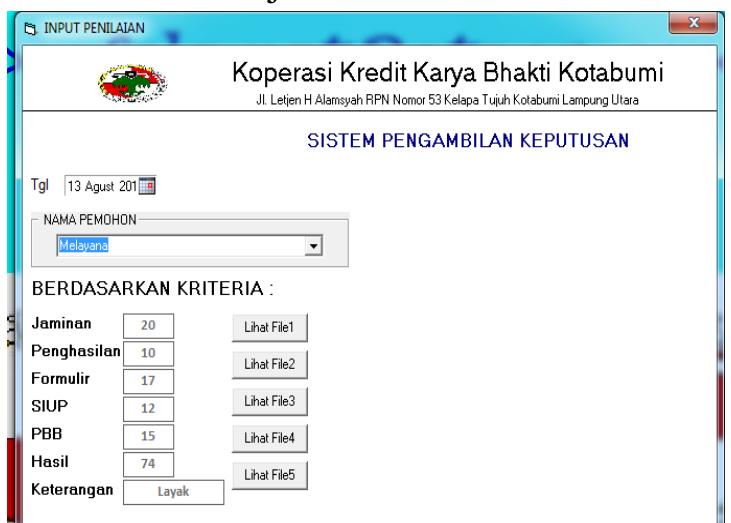


Tampilan Form Laporan Harian

Berikut gambar tampilan form laporan harian.

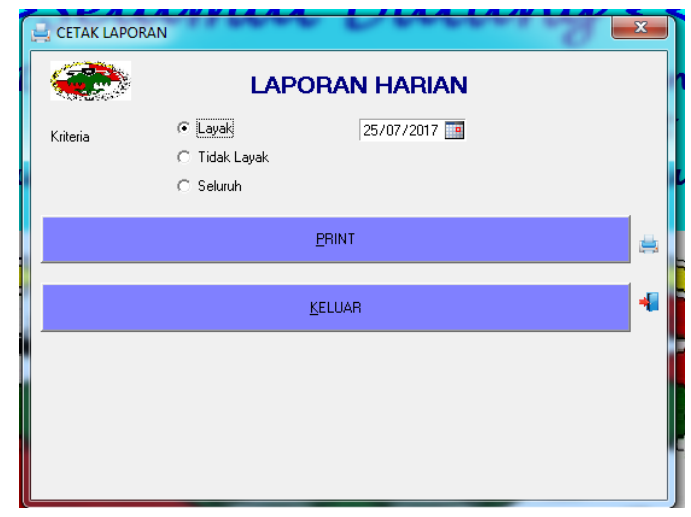

Gambar 7 Form Laparan Harian

\section{Bulanan \\ Tampilan Form Laporan \\ Berikut gambar form laporan} bulanan

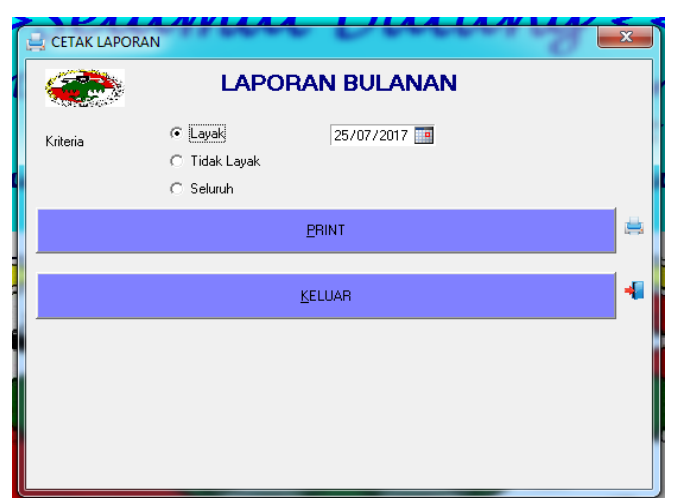

Gambar 8 Form Laporan Bulanan

Tampilan Form
$\begin{gathered}\text { Laporan } \\ \text { Berikut } \\ \text { laporan tahunan }\end{gathered}$

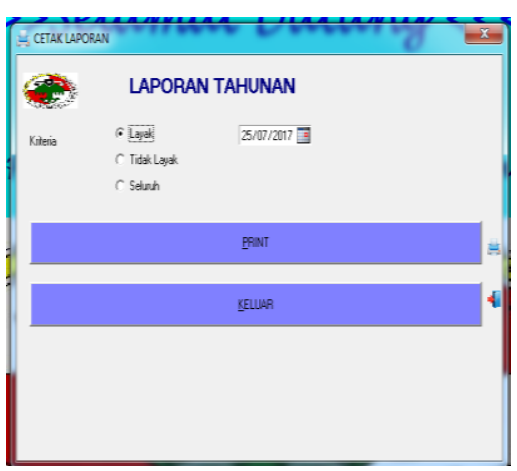

Gambar 9 Form Laporan Tahunan

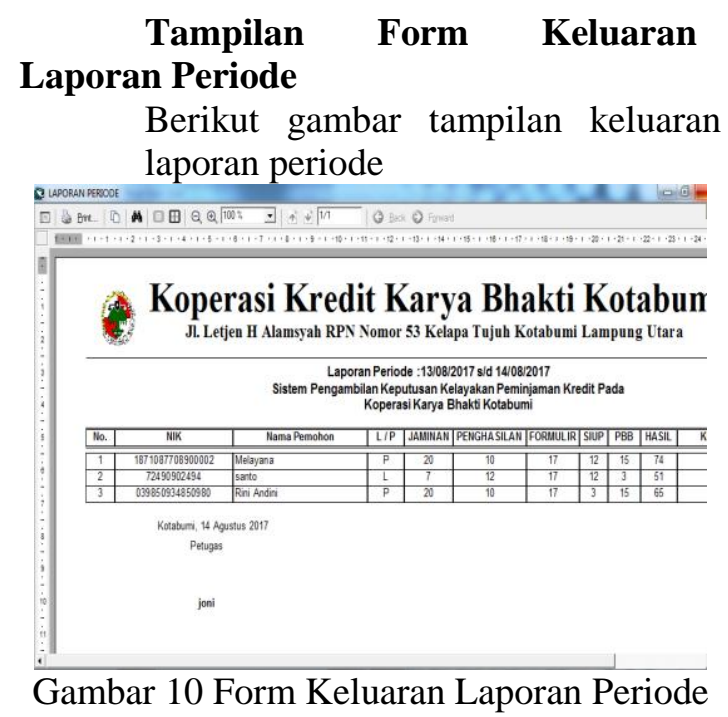




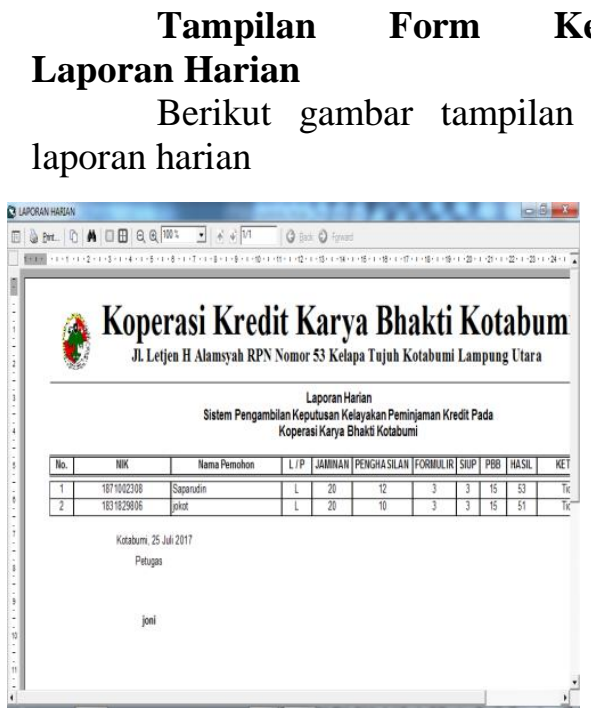

Gambar 11 Form Keluaran Laporan Harian

\section{Tampilan Form Keluaran \\ Laporan Bulanan}

Berikut gambar tampilan keluaran laporan bulanan

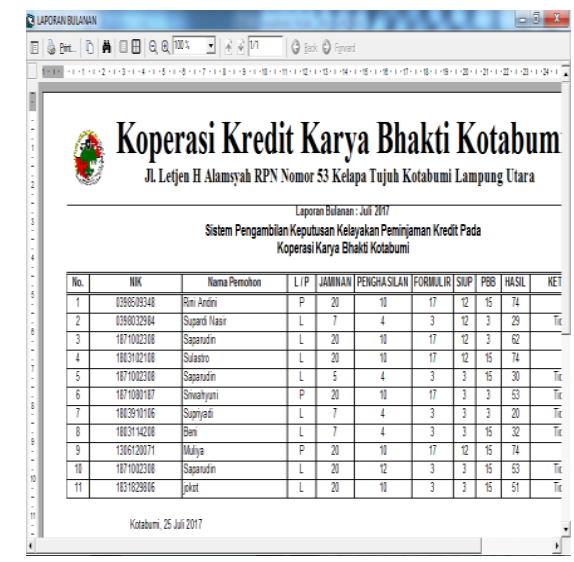

\subsection{Pembahasan Hasil Program}

Hasil penelitian ini merupakan sebuah program aplikasi yang berguna dan bermanfaat untuk mengambil keputusan kelayakan peminjaman kredit Pada Koperasi Karya Bhakti Kotabumi.

Adapun program tersebut berupa menu utama yang terdiri dari :

a. Menu Master

\section{Data Pemohon}

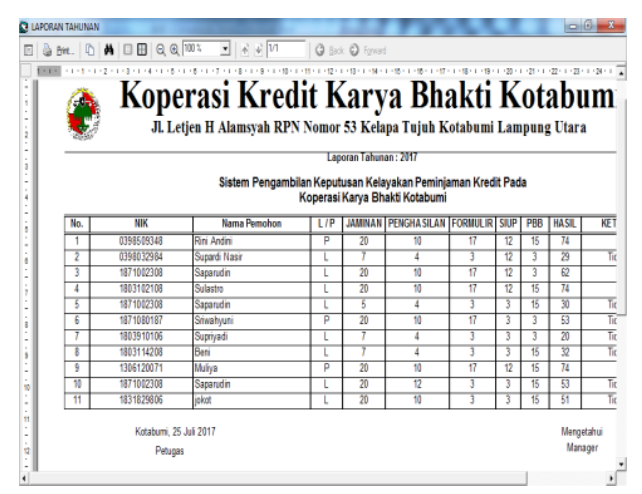

Gambar 12 Form Keluaran Laporan Bulanan

\section{Tahunan \\ Berikut gambar tampilan keluaran laporan tahunan}

Form Keluaran Laporan

Gambar 13 Form Keluaran Laporan Tahunan

\section{Data Petugas}

b. Menu Data Penilaian

1. Input Nilai

2. Penilaian Peminjaman

c. Menu Cetak

1. Laporan Harian

2. Laporan Bulanan

3. Laporan Tahunan

4. Laporan Periode

Tobol-tombol yang terdapat pada program aplikasi ini adalah sebagai berikut :

1. Simpan, tombol ini berfungsi untuk menyimpan dan menambahkan data baru.

2. Edit, tombol ini berfungsi untuk mengubah atau memperbaiki data yang sudah ada jika terdapat kekurangan atau kesalahan dalam pengisian data.

3. Hapus, tombol ini berfungsi untuk menghapus data. 
4. Keluar, tombol ini berfunsi untuk mengakhiri program yang sedang berjalan.

5. Tambah, tombol ini berfungsi untuk menambah data baru

\section{Form Login}

Pada program Login, User harus menginputkan username dan password dan login berdasarkan level, dan ketika penginputan benar maka akan masuk pada menu utama.

\section{Form Menu Utama}

Pada program menu utama, User dapat memilih pilihan yang ada dengan cara mengklikan tombol pilihan yang sudah tersedia seperti master, data penilaian, cetak dan keluar.

\section{Form Data Pemohon}

Pada form data pemohon apabila User ingin memasukkan data baru pertama kali oleh user dengan cara memilih tombol tambah. Kemudian user memasukkan data pemohon tersebut dan menyimpannya. Dan User dapat merubah dan menghapus data tersebut ada tombol hapus dan tombol edit. Terdapat enam data yang harus diinput pada form data pemohon tersebut yaitu ; nik ktp,nama pemohon,tempat tanggal lahir,kelamin,alamat dan telepon. Dalam form data pemohon terdapat tombol perintah dalam pengoperasian program yaitu tombol simpan, edit, hapus, keluar, dan tambah. Masing-masing perintah tersebut mempunyai fungsi yang tujuannya untuk membantu dalam pengolahan data pemohon.

\section{Form Data Petugas}

Pada form data petugas apabila User ingin memasukkan data baru pertama kali oleh user dengan cara memilih tombol tambah. Kemudian user memasukkan data petugas tersebut dan menyimpannya. Dan User dapat merubah dan menghapus data tersebut ada tombol hapus dan tombol edit. Terdapat tiga data yang harus diinput pada form data petugas tersebut yaitu ; nama petugas,status petugas,password. Dalam form data petugas terdapat tombol perintah dalam pengoperasian program yaitu tombol simpan, edit, hapus, keluar, dan tambah. Masing-masing perintah tersebut mempunyai fungsi yang tujuannya untuk membantu dalam pengolahan data petugas.

\section{Form Penilaian Pinjaman}

Pada form penilaian pinjaman apabila User ingin memasukkan data baru pertama kali oleh user dengan cara memilih tombol tambah. Kemudian user memasukkan Penilaian Pinjaman berdasarkan kriteria dan menyimpannya. Dan User dapat merubah dan menghapus data tersebut ada tombol hapus dan tombol edit. Terdapat enam data yang harus diinput pada form data penilaian pinjaman tersebut yaitu ; nama pemohon, jaminan, penghasilan, nilai formulir pengajuan, siup, pbb. Dalam form penilaian pinjaman terdapat tombol perintah dalam pengoperasian program yaitu tombol simpan, edit, hapus, keluar, dan tambah. Masing-masing perintah tersebut mempunyai fungsi yang tujuannya untuk membantu dalam pengolahan data petugas.

\section{Form Laporan Harian}

Untuk memperoleh data laporan harian user memilih pilihan laporan harian dan program akan menampilkan seluruh laporan harian. Untuk mencetak ke printer user dapat menggunakan fasilitas yang ada dengan mengklik icon printer.

\section{Form Laporan Bulanan}

Untuk memperoleh data laporan bulanan user memilih pilihan laporan bulanan dan program akan menampilkan seluruh laporan untuk setiap bulannya. Untuk mencetak ke printer user dapat menggunakan fasilitas yang ada dengan mengklik icon printer.

\section{Form Laporan Tahunan}

Untuk memperoleh data laporan tahunan user memilih pilihan laporan tahunan dan program akan menampilkan seluruh laporan untuk setiap tahunannya. Untuk mencetak ke printer user dapat 
menggunakan fasilitas yang ada dengan

\section{KESIMPULAN}

Berdasarkan hasil dan pembahasan dapat ditarik kesimpulan hasil sistem pengambian keputusan kelayakan peminjaman kredit menggunakan metode Analytic Hierarchy Process (AHP) pada Koperasi Karya Bhakti Kotabumi maka didapatkan beberapa kesimpulan antara lain :

1. Pengolahan data yang terkomputerisasi dengan menggunakan software Microsoft Visual Basic 6.0 akan memudahkan dalam mengambil keputusan dalam penentuan kelayakan peminjaman kredit berdasarkan kriteria dan mengurangi resiko kehilangan datadata penting, karena semua data yang diproses dengan menggunakan aplikasi ini dapat disimpan kedalam database.

2. Sistem yang dibuat dapat digunakan untuk menyelesaikan permasalahan pengambilan keputusan dalam menentukan kelayakan peminjaman kredit sehingga membantu memudahkan pihak Koperasi Karya Bhakti Kotabumi dalam memutuskan masalah yang dihadapi pada saat proses menentukan kelayakan peminjaman kredit.

Simarmata Janner. 2010. Rekayasa Perangkat Lunak. Yogyakarta.

A.Yatini.2011.Flowchart, ALgoritma, dan Pemogrman,Mengunakan Bahasa C++ Builde. Yogyakarat:Graha Ilmu.

A.Ladjamudin.2013.Analisis dan Desain Sistem Informasi.Yogyakarta:Graha Ilmu.

Andira Rizka. 2014.Sitem Pendukung Keputusan Dengan Metode AHP (contoh kasus pemilihan ponsel).http://rizkaandira.blogspot.com/20 14/04/sistem pendukung keputusan dengan.html.Jakarta.Diakses tanggal 20 mei 2017 mengklik icon printer.

3. Metode AHP (Analytical Hierarkhi Process) sesuai untuk diaplikasikan dalam menentukan kelayakan peminjaman kredit dengan menentukan nilai bobot dari setiap kriteria sehigga pihak Koperasi Karya Bhakti Kotabumi dapat mengambil keputusan menentukan kelayakan peminjaman kredit tersebut.

\section{SARAN}

Disamping beberapa kesimpulan tersebut peneliti juga mencoba memberikan saran kepada Koperasi Karya Bhakti Kotabumi sebagai berikut :

1. Menerapkan sistem pengambilan keputusan yang diusulkan untuk proses pengambilan keputusan kelayakan peminjaman kredit karena kemampuan kerja aplikasi ini lebih baik.

2. Diupayakan dapat mengoptimalkan dengan menggunakan program aplikasi Microsoft Visual Basic 6.0 untuk menghindari kesalahan dan pengoperasiannya, sebaiknya memberikan pelatihan kepada user yang akan mengoperasikan program tersebut guna mencapai hasil yang maksimal.

3. Mengembangkan sistem ini dengan menggunakan jaringan dan internet.

\section{DAFTAR PUSTAKA}

Faqot Aviv.2010.10 Definisi Sistem Pengambilan Keputusan (SPK). Jogyakarta.Diakses tanggal 15 mei 2017

$\begin{array}{lr}\text { Haryono Budi.2011.Sistem } & \text { Penunjang } \\ \text { Keputusan dengan } & \text { metode } \\ \text { AHP.Kudus.Jurusan Sistem } & \text { Informasi } \\ \text { Universitas Muria Kudus. } & \end{array}$

Ulum Miftahul.2012.Sistem Pendukung Keputusan Penyetujuan Penerbitan Buku Dengan Metode AHP. Jogyakarta.Diakses tanggal 20 mei 2017

Permana Jayanta.2011.Rancang Bangun Sistem Pendukung Keputusan Pemilihan Paket.

http://digilib.stikom.edu/detil.php?id=1409 \&q.Surabaya. Diakses tanggal 20 mei 2017 
